\section{International Scientific Journal Theoretical \& Applied Science}

Azer Nadir ogli Adigezalov Head teacher of the chair of "History of Uzbekistan" of Andizhan State University Andizhan, Uzbekistan Azerbay23@mail.ru

Shavkat Komiljon ogli Rasulov student of Historical Faculty Andizhan State University`s Andizhan, Uzbekistan

SECTION 13. Geography. History. Oceanology. Meteorology.

\title{
THE PARTICIPATION UZBEKISTAN AND AZERBAIJAN WITHIN THE FRAMEWORK OF PROJECT TRACECA
}

\begin{abstract}
In this article it is given brief information about the origin and development of TRACECA, corridor of Eurasia, as well as the role and importance of economic and cultural relationship among countries which are situated along the Great Silk Road. Within the framework of this project a special place is given to the cooperation of Azerbaijan and Uzbekistan. Due to the participation of the two countries to roads rehabilitation of the Great Silk Road, the work on reconstruction of motor and railway roads and other traffic communications, and also of their infrastructure is held in the republics. The article also includes the examples of efficient and successful cooperation between the two countries.

Key words: Azerbaijan, Uzbekistan, Caucasus, Central Asia, Great Silk Road, the East, the West, civilization,TRACECA.

Language: English

Citation: Adigezalov AN, Rasulov SK (2016) THE PARTICIPATION UZBEKISTAN AND AZERBAIJAN WITHIN THE FRAMEWORK OF PROJECT TRACECA. ISJ Theoretical \& Applied Science, 06 (38): 45-50.

Soi: http://s-o-i.org/1.1/TAS-06-38-10 Doi: crossef http://dx.doi.org/10.15863/TAS.2016.06.38.10
\end{abstract}

In 1991, after disintegration of the USSR, European Alliance has prepared a new, special program TASIS on undertaking the functioning, in particular, the realization of the democratic reforms in independent states, create the infrastructures of market economy, the development of interstate trade, transport, network customs - admission points. Within the framework of exactly this program in 1993 in Brussels "Transcaucasia transport corridor Europe-Caucasus-Asia" project was brought forth on the initiative of European Union (TRACECA) [Gasanov, 2007, p. 601].

As it is well known, in May, 1993 TRACECA was created at the participation of 8 countries: Azerbaijan, Armenia, Georgia, Kazakhstan, Kirgizstan, Tadzhikistan, Turkmenistan and Uzbekistan. Later, during the period from 1996 till 1998 the Ukraine, Mongolia and Moldova were joined to the project. In 2000 Turkey, Romania and Bulgaria were joined to the project. In 2009 Iran was joined to the project, but Lithuania has got the status of the observer in the intergovernmental commission of the organizations.

TRACECA (Transport Corridor Europe Caucasus Asia) is a single project of Euro-Asian transport corridor on the West- East direction from Europe, with intersection of the Black Sea, through
Caucasus and the Caspian Sea with output on Central Asia, which got significant financial, organizational and technical support of the international structures, in the first place of European Union. It corresponds to the global strategy of EU on rendering the assistance to political and economic independence of Central Asian and South Caucasus states by increasing the possibility of their yield on European and world market through alternative transport corridors. Finally TRACECA contacts with TransEuropean Networks (TENs).

Besides, the support of the corridor pursues the purpose to provide guaranteed, steady output of Caspian and under Caspian power resource on international market. Annual financing of TRACECA project by EU forms 9-11 mln. Euro. The TRACECA corridor is aptly located between the main commodity producer in Asia and users in Europe and, besides, this route is more than two times shorter on the main transoceanic direction from the ports of Japan to the largest ports of West Europe.

The main purposes of the project are: creating the alternative to Russian Trans-Siberian pathway; the joining of the region to European transport networks; the support of CIS' (the Commonwealth of independent states) new states independence 
[http://www.transcaspian.az]; the fortification of cooperation between the republics in questions of the trade development in the region; the assistance of Central Asia - Trans Caucasus - Europe corridor development; the determination of the problems and defects in the systems of trade and transport in the region; the determination within the framework of contents and periods of the technical assistance realization program, budgeted by European Union [EVROPEYSKIY..., p. 4].

TRACECA project provided the creation of system collection of railway, car, water and air pathways, which would connect two final points with the most short complexion : Druzhba (Friendship) station on Kazakhstan-Chinese border and Georgian Batumi port with two parallel corridors: Shymkent Tashkent - Samarkand - Bayram- Ali- Ashgabad Turkmenbashi - Baku and Shymken - Aktyubinsk Makat- Aktau - Baku [Mirzaev, 2004, p. 187].

Today, this transport route comprises trainferries between the ports of the west seaside of the Black Sea and Georgia, a modernized TransCaucasian railway and car roads parallel to her, trainferries - Baku - Turkmenbashi and Baku - Aktau with eight ferries, modernized Central Asian railway Turkmenbashi - Ashgabad - Tashkent - Almaty Chinese border and the road of Aktau - Central Kazakhstan - Chinese border, Aktau -North Kazakhstan - Russia, as well as car roads of the latitudinal direction [Fedotova, 2004].

At the present time TRACECA has 64 terminated and 6 current projects on technical assistance, in each of which at the minimum, 10 countries-participants are involved:

The International projects of the transport corridor development are:

1) TRACECA Project on Safety of the road transport II (car roads);

2) Transport dialogue and interaction of the networks II (multimodal transportation);

3) Sea protection and safety II;

4) Project on civil aviation II;

5) Project on Safety of the civil aviation;

6) Regional project of TRACECA -LOGMOS Logistical processes and sea pathways II (multimodal transportations) [Turaeva, 2014, p. 18].

The list of terminated project comprises projects of technical help, concerning development of all types of transportation, education of branch department employee, different TEO development, support, rehabilitation and construction of the roads, introduction of the managerial systems and national legislation change.

The main achievement of TRACECA is the main many-side agreement (MMA) about the international transport on the development of "Europe - Caucasus - Asia" transport corridor, which was signed in Baku in 1998. Apart from MMA, the states, participating in TRACECA, had also taken a number of protocols and technical applications, presenting the change and additions to the given to agreement. Among them it is possible to note the Protocol about contributing changes to MMA, approved on II annual meeting in Tashkent, including the following positions: about railway invoice; about using zero rate VAT on railway facilities and none-using customs deposit; about bank provision; about policy of financial risks insurance and ensuring of the goods transit by rail-freight traffics.

The important action in the development of the transport corridor is the creation of the Coordinating committee on the development of Trans-Caspian international transport route at the participation of railway and port administration and shipping companies of Kazakhstan, Azerbaijan, Georgia and Turkey in February, 2014. Its purpose is the increasing the route attractiveness at the expense of the interaction of the sides in removal of physical and none-physical barriers and coordinated competitive tariff policy conduction [Transport corridors, 2015, p. 38].

One of the main stages of the recovering the transcontinental route are Serakhs Agreement and the Agreement between the Republic of Azerbaijan, Sinker, Turkmenistan and the Republic of Uzbekistan about the forming of communicational Trans-Caucasus corridor, signed in May, 1996.

The Serious achievement in the development of international transport corridors is the introduction to action of Tedzhen-Serahs-Meshhed pathway under active participation of Uzbekistan railway on May 12, 1996, extending $320 \mathrm{~km}$, which has opened new Trans-Asian corridor for the yield of Central Asian countries on the world market through the territories of Iran and Turkey. In the same year in Serahs the leaders of Uzbekistan, Azerbaijan, Georgia and Turkmenistan have signed "The Agreement on the co-ordination of activity of the rail-freight traffic" and "The Agreement on cooperation in the field of regulations of transit transportation between countries-participants" [http://www.uzyt.uz/index].

The Trans-Caucasus corridor (in transit through Turkmenistan, Kazakhstan and Azerbaijan), with output to the Black Sea is known as TRACECA corridor. According to preliminary estimates of analysts, the realization of the project will allow Uzbekistan to spare annually around $20 \mathrm{mln}$ USA dollars only on the export of cotton filament. As to economic advantages the opening of the new pathway allows Uzbekistan to shorten the distance to ports of the Black Sea basin to 1500 kilometers in contrast with traditionally used "northern" routes. Today, the transportation of one ton of the cargo on TRACECA costs cheaper by 14-18 USA dollars than the former way through Russia.

For present day, the fact that Uzbekistan, having already put money into the reconstruction of the 
Black Sea transshipment element, Poti port, which has 3 own storehouses there today, with the capacity of 30 thousand tons, tells in favour of this route.

This route is one of the the most real possibilities of Central Asian countries yield (including Uzbekistan) to the seaports on TashkentChardzhou-Turkmenbashi- Baku -Poti (Batumi) route, as well as by the united system overland car and railway communications formed long ago, connecting the countries of Central Asian region and Transcaucasia with European continent.

Within the framework of this route the car road passes on the territory: Azerbaijan - $801 \mathrm{~km}$; Georgia - 464 km; Uzbekistan - 662 km; Turkmenistan - 1212 $\mathrm{km}$. On experts' evidence this car route has the first, the second and the third technical categories and allows skipping the transport facilities through traffic, at the term of the bridges' reconstructions and some area on the territories of Azerbaijan, Turkmenistan and Georgia.

The Railway route on Euro-Asian corridor, having its total extent of $3076 \mathrm{~km}$, passes the territories: Azerbaijan (the Baku- Buyuk Helmet) 511 km; Georgia (Buyuk Helmet- Port Poti) -363 km; Uzbekistan (Chingildy-Farab) - 761 km; Turkmenistan (Farab-Turkmenbashi) - $1141 \mathrm{~km}$. It should be mentioned that this railway pathway, having its enough high reception capacity about 40 pairs train a day, is well equipped and is partly electrified [http://refdb.ru/look/1 735317.html].

Besides the development of the two main trends: car and rail transportations, technical assistance in the development of the sea transportations turns out to be too. The investment projects on the development of the terminal infrastructures in the ports of Iliichevsk, Poti, Batumi, Turkmenbashi, Baku and Aktau have already been marketed as a result Varna-IliichevskPoti-Batumi and Baku -Aktau regular train-ferry link has been opened. Simultaneously these ports are given necessary equipment for the realization of the cargo handlings, including the processing of containerized cargo.

One of the most important transport elements of Europe - Caucasus - Asia route on the Caspian Sea is Baku international seaport. It has several mechanized quays, which are specialized on processing of dry cargo and fluid courts, as well as on processing of ferry and heavy-load containers. At the expense of the grant the port has gained modern cargo-handling equipment for the amount of $2 \mathrm{mln}$. dollars [Mirzaev, 2004, p. 235] as a result of that an oilcargo-port is delivered in usage, allowing unloadloading of $10 \mathrm{mln}$, oil-products per annum. Besides, some works on the reconstruction of Baku International Trade Port ferry terminal are held.

If in 1996 the volume of Uzbek export-import cargo transported on Trans-Caucasus corridor formed nearly 140 thousand tons, in 1997 it formed 285 thousand tons, and only within eight months of 1998 it exceed 240 thousand tons. With the operation of the route beginning only within the framework of cooperation with Uzbekistan on export-import operations 660 thousand tons of vitally important cargo on the amount of about $470 \mathrm{mln}$. USA dollars have been transported [Karimov, 1999, p. 172]. The Main transit cargos are oil products and cotton.

Azerbaijan and Uzbekistan consider questions of more efficient Trans Caucasus corridor use within the framework of TRACECA project, EuropeCaucasus-Asia route as an important factor for growing of the amount of business between the two countries [Gasanov, 2007, p. 737].

However, among all types of transport a special place for South Caucasus countries and Central Asia is occupied by the pipe lines, the main task of which is delivery of the power systems through the Caspian and the Black Sea in Europe. Today Turkmenistan is predicted the fate of Kuwait for great spares of oil and gas, Azerbaijan and Kazakhstan are numbered among the countries with great prospects, and Uzbekistan will be able to provide itself independence in power engineering even for a long time [Mirzaev, 2004, p. 159].

The pipe lines in the Caspian region are a powerful instrument of geopolitics. Baku - Supsa oil pipeline have been laid first on South-Caucasus corridor on April 17, 1999, at the participation of the President of the Republic of Azerbaijan, Geydar Aliev, the President of Georgia, Eduard Shevardnadze, and the President of the Ukraine, Leonid Kuchma, the ceremony of the exploitation of Baku - Supsa oil pipeline and Supsa terminal (located on the Chernomorsk seaside of Georgia) was held. Through Supsa port the export of Azerbaijan oil which was gained from "Chyrag" oil-field on the world market began [www.azerbaijan.az]. The Total extent of the oil pipeline is $850 \mathrm{~km}$, the reception capacity is 5 million tons per annum [Guseynova, 2005, p. 228].

The Project of Baku - Tbilisi - Dzheyhan pipe line began to be realized after signing of the declaration on October 29, 1998 in Ankara. It has been signed by the President of Azerbaijan, Geydar Aliev, the President of Georgia, Eduard Shevardnadze, the President of Kazakhstan, Nursultan Nazarbaev, the President of Turkey, Suleiman Demirel, and the President of Uzbekistan, Islam Karimov, in witness of the minister of the USA power engineering, Bill Richardson [Baran, 2005, p. 106]. The extent of Baku - Tbilisi Dzheyhan pipeline makes up 1768 kilometers. The oil pipeline passes through the territories of three countries: Azerbaijan $(443 \mathrm{~km})$, Georgia $(249 \mathrm{~km})$ and Turkey $(1076 \mathrm{~km})$. The reception capacity makes up 1,2 mln. barrels of oil a day. The Official ceremonial openning of the whole oil pipeline passed on July 13, 2006 in Dzheyhan. Since the moment of 
the putting the oil pipeline into operation on June 4, 2006 and on condition at the end of June, 2013, altogether 2227 tankers were loaded in Dzheyhan port, i.e. on BTD $229 \mathrm{mln}$. tons of oil were got to the world markets. At present oil is pumped on BTD oil pipeline from the block of "Azeri-Chirag-Gyuneshli" oil-field and the condensate from "Shah-Deniz" oilfield [http://www wikipedia.org].

On June 16, 2006 Nursultan Nazarbaev signed the agreement on joining Kazakhstan to the project of the oil pipeline. The Agreement provides the organization of tanker transportation to Kazakhstan's oil from Aktau to Baku through the Caspian Sea and its further transportation on BTD oil pipeline. On the first stage Kazakhstan intends to load on BTD about 7,5-10 mln. tons of oil per annum.

It is interesting that on the ceremonies of the BTD's opening Nursultan Nazarbaev has elaborated that Dzheyhan direction will become for Kazakhstan only one of the export oil ways, but in no circumstances the main one. He founded his own discourses just on the forecasts of the mining of oil in the republic. "Astana keeps the many-side variant of its own hydrocarbon delivery to the world market, he said. - And not because this is our ferroconcrete position, but simply because of that in 2010 we shall gain $100 \mathrm{mln}$., and till 2015 we shall gain about 150 $\mathrm{mln}$. tons of oil. Under the internal need of our economy about $30 \mathrm{mln}$. tons neither BTD, nor North Caspian oil pipeline will be able to provide complete transportation of our oil abroad" [Zaslavskiy, 2005, p. 14].

The Significant place in transportation of power resources is conducted also to gas. South Caucasus gas-main, or in other words Baku- Tbilisi - Erzurum (BTE) Gas-main, was officially opened on March 25, 2007. The Diameter of the pipe line is 42 inches, extent makes up $970 \mathrm{~km}$ (442 km in Azerbaijan, 248 $\mathrm{km}$ in Georgia and $280 \mathrm{~km}$ from Georgian-Turkish border to Erzurum). On the South Caucasus gas-main the gas is pumped, which is gained within the framework of the first phase of "Shah-Denis" project [Transport..., 2015, p. 72-73].

Uzbekistan also takes part in dispatch of its own power resources to European countries, through BTD and BTE oil pipelines, using the ports of Kazakhstan and Turkmenistan, and from there goods are got to Azerbaijan and further to Europe through Turkey. For transportation of the cargo from Azerbaijan to Uzbekistan, the goods are sent from Baku port to Turkmenbashi port, from which they follow through Turkmenistan on a railway or a car road, further they reach Uzbekistan. There also exists an alternative way through Kazakh port Aktau, from which goods are delivered to Uzbekistan by land.

Besides oil and gas, different equipment, industrial and foodstuffs are also carried.

Within the framework of the corridor some steps are undertaken on shaping the mutually beneficial tariff terms for transportation of humanitarian cargo in Afghanistan, as well as the organizations of containerized transportation on PotiBaku -Aktau- Almaty route with the prospect of their extension to China.

However, under the whole importance and intensities of Transcaucasia route, in 2008 the given route ceded a little to other alternative corridors: Trans-Russian and Trans-Turkish (Iranian) routes.

The time, cost, reliability, safety of the cargo have served as the criteria of comparison, moreover, the higher the importance of the index is, the more attractive the given route is. As any other index, its importance can be evaluated only in comparison with one another.

According to the results of this study the best indicator of transport routes attractiveness was given to Trans-Russian route -3414 , Trans-Turkish one turned out to be on the second place according to this index 6646, and the third place was given to Trans Caucasus route with the index importance -8258 .

The Comparison of the Index TRACECA of alternative routes.

Table 1

\begin{tabular}{|c|c|c|c|c|c|}
\hline Route & $\begin{array}{c}\text { INDEX } \\
\text { Significance }\end{array}$ & Way cost & Time cost & $\begin{array}{c}\text { Reliability } \\
\text { Cost }\end{array}$ & Safety cost \\
\hline Trans Russian & 3114 & 1685 & 6767 & 6373 & 137 \\
\hline Trans-Turkish & 6646 & 3408 & 7776 & 8839 & 221 \\
\hline Trans-Caucasian & 8258 & 3446 & 11243 & 10849 & 300 \\
\hline
\end{tabular}

During the last years within the framework of TRACECA and in alternative fetter cooperation searches of new large-scale project are planned. One of them is NEACB (New European Asian
Continental Bridge) project, being realized within the framework of TRACECA. The Interest to the project is exceedingly great all through the route from China to Turkey. The extent of this transport bridge is 
$10560 \mathrm{~km}, 3900 \mathrm{~km}$ of which pass through the territory of China, $1800 \mathrm{~km}$ pass through the foothills and plains of Kazakhstan, $700 \mathrm{~km}$ pass through Uzbekistan, 450 pass through Turkmenistan, 1960 $\mathrm{km}$ pass through Iran and $1750 \mathrm{~km}$ pass through Turkey. Azerbaijan, Georgia and Armenia are also taken into account to be joined to the project [Mirzaev, 2004, p. 179].

From the very beginning NEACB assumed the construction of the railroad tracks network from Lianyungang coastal city through China to Kazakhstan and Iran and further on the tunnel under the Marble Sea (built in 2013) to Turkey for the reason of ensuring the steady train service between China and Europe. The New Eurasian continental bridge was to become the addendum to TransSiberian pathway, which already provides regular delivery of the cargo between China and Germany. The given project also comprises sea area, passing from China through the Indian Ocean [Transport corridors, 2015, p. 27].

The other project, which must become one of the main TRACECA's routes, is Baku - Tbilisi Kars (BTK) railway. The agreement on its construction was signed in February, 2007 by the presidents of Azerbaijan, I. Aliev, Georgia, M. Saakashvili, and the Prime Minister of Turkey, R. Erdogan. The total extent of the railroad tracks will form $98 \mathrm{~km}, 68 \mathrm{~km}$ of which will go through Turkish territory and $30 \mathrm{~km}$ will go through Georgian territory.

Full operation of this train service is planned in the middle of 2016. On December 24, 2015 on Baku-Tbilisi-Kars (BTK) railway the test cargo train including five coaches, which went from Baku to Ahalkalaki station, was successfully started up. The peak reception capacity of the corridor will form 17 million tons of cargo per annum. On the initial stage this factor will be at the rate of one million passengers and 6,5 million tons of cargo [http://www.trend.az/business/economy/2475882.ht $\mathrm{ml}$.

To the operation of BTK the delivery into usage of Alyat port near Baku is also planned. At the same time Kazakhstan also plans to increase Aktau port, in which an additional ferry terminal will be built. The Improvement of ports on the Caspian Sea will bring even more productive cooperation of TRACECA's countries-participants.

TRACECA project "Silk Wind" also seems to be interesting and, directed on the extension of transit transportation by railway and sea fetter on the direction of China border - Kazakhstan - GeorgiaAzerbaijan - west border of Turkey. The Participants of the project (Azerbaijan, Georgia, Kazakhstan and
Turkey) plan to use the speed through cargo trains in multimodal transportation, to introduce the common tariff on cargo transportation, to simplify customs and border procedures, as well as to shorten the time of the transit and the time for transit.

Within the framework of Silk Wind project the extent and velocity of the transportation on Dostyk/Altynkoli - Kars route through Aktau and Baku ports will practically decrease by $25 \%$ (from 16 to 12 days). The Project provides the introduction of the preliminary exchange system of information between customs service and the participants of the transportation process and expects granting the complex services of the infrastructure of the logistics. In 2013 the experts of all countries designed the project of the agreement, which is planned to be signed in the nearest future. [Transport corridors, 2015, p. 66-67].

At the moment American initiative of the further development of TRACECA, "New Silk way" is realized, in addition to European initiative of TRACECA, which for the first time was announced in 2011 as a possible way of Afghanistan's greater integration to the region. The project comprises traditional approaches such as recovering the trade ways and relationships, reconstruction of the infrastructure, creation of the new transit and "North - South" trade ways, connecting Central Asian countries, Afghanistan, Pakistan, India and other states. For the realization of the project not only reliable and qualitative roads, bridges and border infrastructure are necessary, but also the harmonization of national customs systems so as the neighbouring states could avoid all legal, formal and informal barriers and co-operate effectively.

Besides, the Chinese project "New Silk way" brought forth in the alternative to TRACECA project, which has found its reflection in "One belt one way" approach, announced by PRC Leader, Ci Czinipin, in September, 2013 in Kazakhstan; seems to be interesting. The Project belongs to the trade routes, lying on the lands from China through Central Asia, Iran, Iraq and Turkey (through Bosfor) to Northwest Europe. This approach is more ambitious than New Eurasian Continental Bridge [Transport corridors, 2015, p. 27]. NEACB is a project, spreading to regional scales, and "One belt - one way" is a global one.

Thus, in spite of some difficulties, TRACECA is a project with great future, which will create conditions not only for the productive cooperation between the Republic of Azerbaijan and the Republic of Uzbekistan, but also for all the participants of the project, with prospect of the inclusion of the world scale. 


\begin{tabular}{l|lrl|l|ll} 
& ISRA (India) & $=\mathbf{1 . 3 4 4}$ & SIS (USA) & $=\mathbf{0 . 9 1 2}$ & ICV (Poland) & $=\mathbf{6 . 6 3 0}$ \\
Impact Factor: & ISI (Dubai, UAE) $=\mathbf{0 . 8 2 9}$ & PUHL (Russia) $=\mathbf{0 . 2 3 4}$ & PIF (India) & $=\mathbf{1 . 9 4 0}$ \\
& GIF (Australia) & $\mathbf{0 . 5 6 4}$ & ESJI (KZ) & $=\mathbf{1 . 0 4 2}$ & IBI (India) & $=\mathbf{4 . 2 6 0}$ \\
& JIF & $\mathbf{1 . 5 0 0}$ & SJIF (Morocco) & $=\mathbf{2 . 0 3 1}$ & & \\
\hline
\end{tabular}

\section{References:}

1. Gasanov A (2007) Modern international relations and external policy of Azerbaijan. B. "Sharq-Garb"(East - West). 2007. 904 p.

2. Guseynova I (2005) Geydar Aliev - from a political leader to the national leader. B, "Tahsil", 2005, 504 p.

3. (2016) EUROPEAN UNION - TASIS. The Development of the networks: TRACECA. The Technical requirement. Training for workers of the sea transport Azerbaijan, Georgia, Kazakhstan, Turkmenistan, Ukraine.

4. Zaslavskiy I (2005) Deal pipe. The BakuTbilisi - Dzheyhan and Kazakhstan choice on the Caspian Sea. M, "Europe", 2005, 36 p.

5. Karimov I (1999) We build our future with our own hands. T, "Uzbekistan", 1999. 382 p.

6. Mirzaev R (2004) Geopolitics of the New Silk Way. M. "Izvestiya" (Notify) 2004. 304 p.

7. (2015) The transport corridors of Eurasia: new ways of cooperation: The materials of the international conference (the April 20 2015, Astana) / E.T. Karin. - A.: Kazakhstan institute of the strategic studies under the President of the Republic of Kazakhstan, 2015. - 112 p.

8. Turaeva MO (2014) Transport infrastructure of Central Asian countries in terms of modern regionalization. Report. - M. Institute of the economy RAS. 2014. 62 p. 15)

9. Fedotova S (2004) TRACECA - a way to integration. // Pravda Vostoka (Truth of East).27.07.2004.

10. Zeyno Baran (2005) The Baku-TbilisiDzheyhan Pipeline: Implications for Turkey // the Baku-Tbilisi- Dzheyhan Pipeline: Oil Window to the West - The Central AsiaCaucasus Institute, Silk Road Studies Program, 2005.

11. (2016) Available: http://www.transcaspian.az (Accessed: 10.06.2016).

12. (2016) Available: www.azerbaijan.az (Accessed: 10.06.2016).

13. (2016) Available: http://www.wikipedia.org (Accessed: 10.06.2016).

14. (2016) Available: http://www.uzvt.uz/index (Accessed: 10.06.2016).

15. (2016) Available: http://refd.ru/look/1735317.html (Accessed: 10.06.2016).

16. (2016) Available: http://www.trend.az/business/economv/247588 2.html (Accessed: 10.06.2016). 